\title{
Detection of the enzymes of Gloeosporium kaki in relation to tissue-maceration.
}

\author{
Toshikazu TANI*
}

\section{Introduction}

In connection with the soft rotting in diseased plants, there is extensive literature elucidating the fact that the tissue-maceration of the host is caused by the action of pectolytic enzymes from the pathogens. However, as has been reported in a previous paper ${ }^{11)}$, some evidence has been obtained which suggests the possibility that the softening of kaki fruit invaded by Gloeosporium kaki is not caused by the fungal pectolytic enzymes, but by those produced by the invaded fruit itself.

This paper deals chiefly with types of pectolytic enzymes from the pathogen, and connection of the depolymeric enzymes with the tissue-macerating enzymes acting on kaki fruit.

The author wishes to express his hearty thanks to Prof. Dr. N. Naito for his kind guidance and encouragement throughout this work. Thanks are also due to Prof. Dr. A. Kaji and Asst. Prof. T. Narasaki for their advice and helpful criticism. The study was supported in part by the Grant in Aid for Agricultural Research from the Ministry of Education, to which the author expresses his thanks.

\section{Materials and methods}

The isolate of $G$. kaki used was the same as in the preceding study ${ }^{11)}$. The stock culture had been maintained on a soy agar medium, on which the good growth was obtained, and, as far as could be seen, the fungus remained constant in behavior and cultural characteristics. Although on a kaki solid medium this fungus produced little or no liquefying pectolytic enzyme ${ }^{10)}$, a considerable secretion of pectin-depolymeric enzymes could be detected from the culture filtrate of soy liquid medium $^{12)}$. In this study, therefore, the fungus was grown on the soy liquid medium, $50 \mathrm{ml}$ of the medium being placed in a $200 \mathrm{ml}$ Erlenmeyer flask. The inoculation was made with an agar plug, cut to approximately $0.3 \mathrm{~cm}$, from the edge of $4 \sim 6$ days old Petri-dish culture on the soy agar. After 12 days' incubation at $25^{\circ} \mathrm{C}$ the culture was filtered through filter paper to obtain a filtrate. The partial purification of enzyme activities was followed by the method shown in Fig. 1. The use of this procedure was founded on the results which had been obtained in preliminary experiments. The preparation was stored at $-10^{\circ} \mathrm{C}$ until required, and used as a crude enzyme solution.

The macerating activity was estimated with the disks ( $9 \mathrm{~mm}$ diam. and $0.5 \mathrm{~mm}$ thick.) of potato tuber and kaki fruit (variety Fuyu) tissues; 1 disk was placed in $2.0 \mathrm{ml}$ of each solution containing 1 volume of a test solution, 3 drops of toluol, and 1 volume of McIlvaine buffer, $\mathrm{pH} 5.0$. The mixture was incubated at $35^{\circ} \mathrm{C}$ for 20 hours and the degree of maceration was determined according to the procedure described in the previous paper ${ }^{11)}$.

For the estimation of pectic and cellulolytic enzyme activities the following substrates were prepared.

(a) Pectin : 2 volumes of ethanol were added to a 5 per cent solution of commercial citrus

\footnotetext{
* Faculty of Agriculture, Kagawa University, Kagawa, Japan
} 

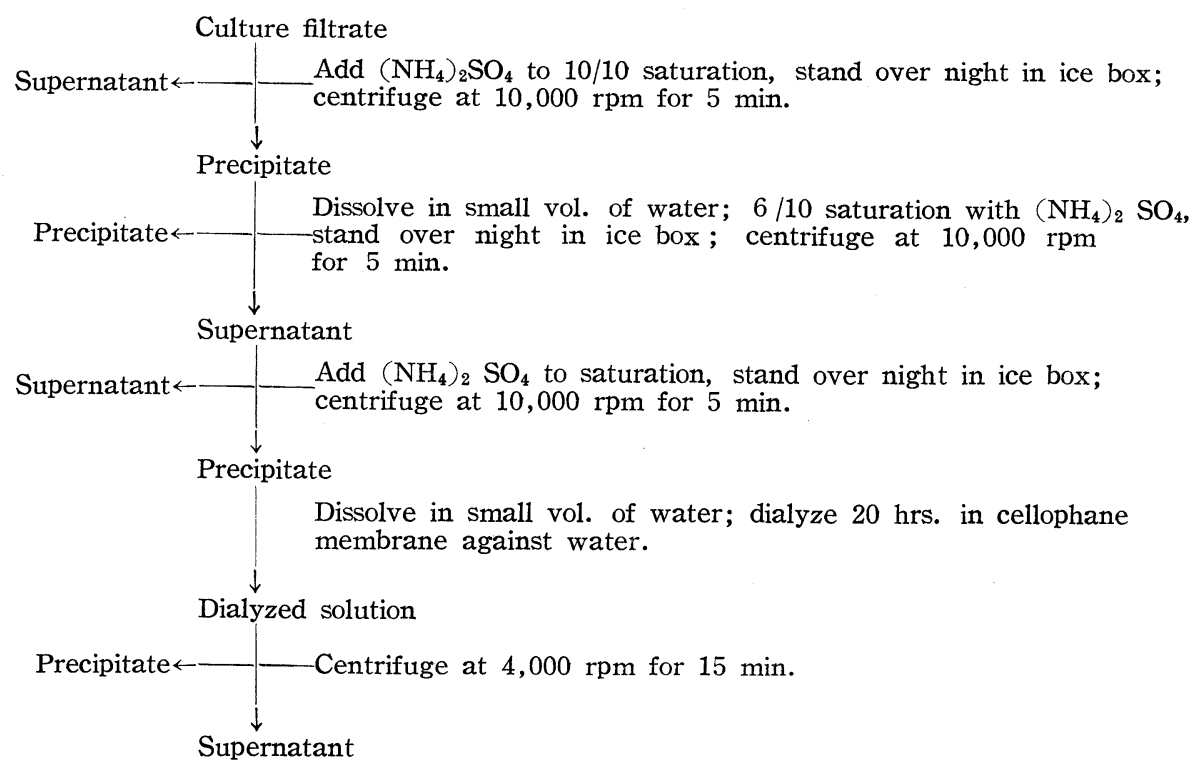

(Crude enzyme solution)

Fig. 1. Preparation of crude enzyme solution.

pectin. The mixture was incubated at $60^{\circ} \mathrm{C}$ for 2 hours. A precipitate produced was separated by filtration, and then suspended into 70 per cent ethanol. The suspension was again incubated at $60^{\circ} \mathrm{C}$ for 2 hours. By this process of $3 \sim 4$ fold replication, the reducing materials contained in pectin were removed.

(b) Pectic acid: $5 \mathrm{~g}$ of commercial citrus pectin was dissolved in $100 \mathrm{ml}$ of $\mathrm{N} / 10 \mathrm{NaOH}$ at $50^{\circ} \mathrm{C}$, and kept for 2 hours. Then 2 volumes of $\mathrm{HCl}$-ethanol were added. A precipitate produced was washed with 70 per cent ethanol until free of chloride.

The both preparations were washed successively with 85 per cent, 95 per cent, and absolute ethanol, and finally with ether to be dried. They were dissolved in water to 1 per cent before application. The methoxyl contents of the purified pectin and the pectic acid were estimated by using the method of Hewitt and Jones') to be 8.71 per cent and 1.74 per cent (oven dry basis), respectively.

(c) Na-CMC: Commercial sodium carboxymethyl cellulose was used, without purification, by dissolving in water to 0.5 per cent.

The reaction mixture was prepared by adding $2.5 \mathrm{ml}$ of a substrate solution and $1.0 \mathrm{ml}$ of McIlvaine buffer to $1.5 \mathrm{ml}$ of a testing solution of enzyme activity. The $\mathrm{pH}$ value of the reaction mixture was adjusted to 5.0 unless otherwise indicated. In addition to the above, 3 drops of toluol were added for the saccharifying experiments.

The depolymeric activity was determined by measuring the viscosity 'decrease Iwith an Ostwald viscometer at $35^{\circ} \mathrm{C}$ in a water bath, and $\mathrm{A} \%$ or PMG-unit was calculated according to the description of $\mathrm{Kaji}^{5)}$. The determination of saccharifying activity was made by titrating the reducing sugar, which was liberated by the incubation of reaction mixture at $35^{\circ} \mathrm{C}$ for 20 hours, with sodium thiosulphate according to the method of Somogyi-Schaffer-Hartmann. The activity was expressed as the volume in $\mathrm{ml}$ of a N/200 Na $\mathrm{Na}_{2} \mathrm{O}_{3}$ solution consumed or as the weight in $\mathrm{mg}$ of glucose by calculation.

Zone electrophoresis was performed according to the procedure of Kaji et al. ${ }^{6}$. An apparatus of Toyo Roshi Co. was used for the electrophoretic migration. Potato starch employed for a supporting medium was washed repeatedly with water and adjusted to $\mathrm{pH} 7.4$ with $\mathrm{M} / 50$ phosphate buffer. 
It was then packed in a tray of plastics $(25 \times 3 \mathrm{~cm}$ base and $1.4 \mathrm{~cm}$ height) by tapping, and an excess liquid was removed with filter paper. $0.7 \mathrm{ml}$ of the partially purified enzyme solution was charged to the starch block, which was preincubated at $0 \sim 5^{\circ} \mathrm{C}$. The both ends of the block were connected to the electrolyte vessels with filter papers. The apparatus was placed in a freezer, and was kept at $0 \sim 5^{\circ} \mathrm{C}$ during the electrophoretic migration. The electrophoresis was conducted at potential gradients of $240 \sim 260 \mathrm{~V}$ or $350 \sim 370 \mathrm{~V}$, giving currents of $4 \sim 7 \mathrm{~mA}$ or $8 \sim 10 \mathrm{~mA}$, respectively. After appropriate hours the starch block was cut into $2 \mathrm{~cm}$ segments, and the enzymes were eluted with 2.0 or $6.0 \mathrm{ml}$ of water.

Other experimental details will be given later.

\section{Results}

\section{1) Separation of the enzymes by zone electrophoresis}

The crude enzyme solution was obtained by diluting the crude preparation with water to give the concentration of $1,000 \sim 3,000$ PMG-unit per $\mathrm{ml}$. It was then used as a sample for the electrophoresis. This solution also reduced the viscosity of pectic acid and Na-CMC, but did not remove the methoxyl radical of pectin.

Fig. 2 shows the presence of two kinds of depolymeric enzymes on pectic substances, both migrating toward cathode. By this electrophoresis cellulase $\mathrm{Cx}$ could not be separated from the pectolytic enzyme which was found in the fraction 3. However, when the electrophoresis was carried out at the condition in Fig. 3, the maximum points of the both activities were completely separated one another. Saccharifying activities were also estimated on each fraction obtained by the electrophoresis which was performed under the same condition as that of Fig. 2. The results are given in Fig. 4. Although any fraction active on Na-CMC was not found, two pectolytic activities appeared, both migrating toward the same electrode as the depolymeric enzymes did. In the fraction 8 both liquefying and saccharifying activities were higher on pectic acid than on pectin. Perhaps, the same enzyme would be measured by different methods. In the fraction 3 , the difference in a degradation degree between both substrates was found. The very active saccharifying activity found in the fraction 3 may indicate the presence of another enzyme such as exo-polygalacturonase. Further electrophoresis was carried out in an attempt to separate the saccharifying activity from the liquefying activity, but as shown in Fig. 5, the two activities did not separate at all. No effective result was obtained when cellulose powder was used as the supporting medium.

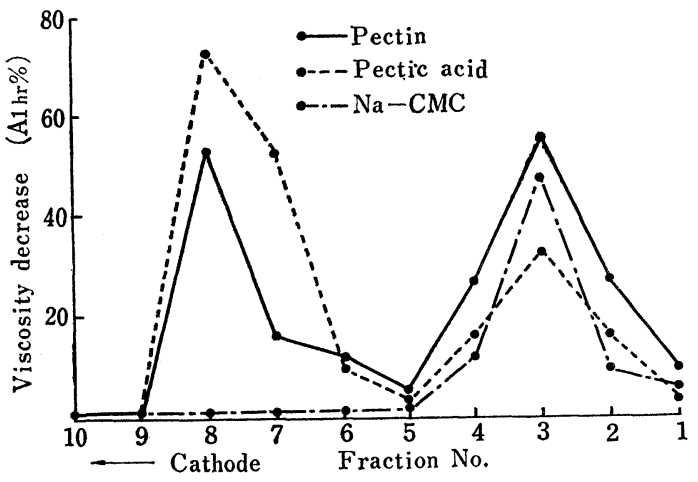

Fig. 2. Zone electrophoresis of liquefying activities on pectin, pectic acid, and $\mathrm{Na}-\mathrm{CMC}$.

$250 \mathrm{~V}, 5 \sim 7 \mathrm{~mA}, 15$ rhs., pH 7.4

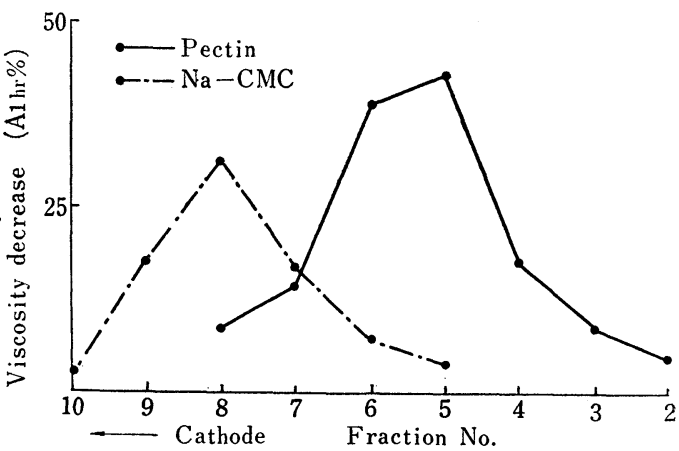

Fig. 3. Zone electrophoresis of liquefying activities on pectin and Na-CMC. $350 \mathrm{~V}, 8 \sim 10 \mathrm{~mA}, 24 \mathrm{hrs.}, \mathrm{pH} 7.4$ 


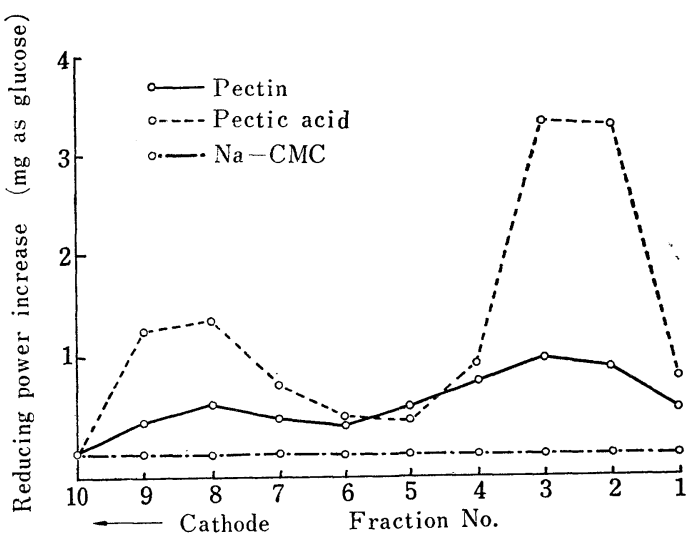

Fig. 4. Zone electrophoresis of saccharifying activities on pectin, pectic acid, and $\mathrm{Na}-\mathrm{CMC}$.

$250 \mathrm{~V}, 5 \sim 7 \mathrm{~mA}, 15 \mathrm{hrs} ., \mathrm{pH} 7.4$ : titration sample $4.0 \mathrm{ml}$

\section{2) Properties of the pectolytic enzymes}

Some properties were detected by using the elu. ates from the fractions 3 and 8 , which were obtained by the electrophoresis shown in Fig. 2. Fig. 6 and Table 1 give the data to determine the behaviors of the pectolytic enzymes. In each of these experiments, the measurement of the activities on pectin and pectic acid was made by using the same enzyme solution diluted with water to desired concentration. In the fraction 8 the decrease in the viscosity of pectic acid was greater than that of pectin. Similar property was also found for the saccharifying activities, though the increase of the reducing power was not so remarkable as the decrease of the viscosity. Therefore, the enzyme contained in this fraction will be depolymeric polygalacturonase (endo-PG). On the contrary, the fraction 3 reduced the viscosity of pectin solution more markedly than that of pectic acid solution. As shown in Table 1, a remarkable increase was found in the reducing power of pectic acid solution. When both fractions were adjusted to almost equal depolymeric activity, approximately $30 \mathrm{~A} \mathrm{hr} \%$ on pectic acid, the reducing power increase of the fraction 3 was about 11 times as large as that of the fraction 8 . This result may indicate the presence of both depolymeric polymethylgalacturonase (endo-PMG) and saccharifying polygalacturonase (exo-PG).

To find out further disparity among these activities, the effect of $\mathrm{pH}$ on the pectolytic degradation was examined. In this experiment, the fraction 8 was used as an endo-PG solution, and the fraction 3 was used as an endo-PMG or an exo-PG solution. Preparations over the $\mathrm{pH}$ range $2.5 \sim 7.0$ were set up with Mcllvaine buffer, and the results are given in Fig. 7. Activities of endo-PG, endo-PMG and exo-PG were greatest at $\mathrm{pH} 5.5,4.5$, and 5.0, respectively. Thus, differences among these enzyme activities were also found in their pH-activity curves. 
It is evident from the results of this section that $G$. kaki produces three kinds of pectolytic enzymes. A case that a single isolate of a pathogenic fungus produces both endo-PG and -PMG has been reported with Ceratocystes fimbriata ${ }^{14)}$.

3) Determination of macerating activity

Preliminary tests with the crude enzyme preparation from the soy liquid culture showed that considerable concen-
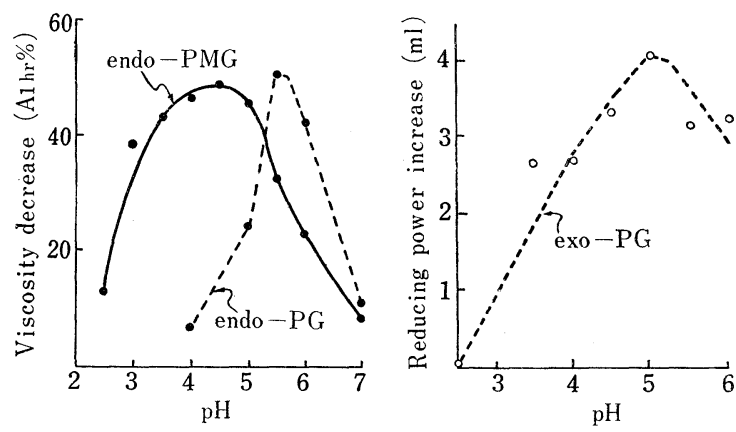

Fig. 7. pH-activity curves of the pectolytic enzymes.

Table 1. Saccharifying behabiors of the pectolytic enzymes.

\begin{tabular}{cccc}
\hline \hline Fraction No. & Substrate & $\begin{array}{c}\text { Viscosity decrease } \\
\left(\mathrm{A}_{1} \mathrm{hr} \%\right)\end{array}$ & $\begin{array}{c}\text { Reducing power } \\
\text { increase }(\mathrm{ml})\end{array}$ \\
\hline 3 & $\left\{\begin{array}{l}\text { Pectin } \\
\text { Pectic acid }\end{array}\right.$ & 60.9 & 2.90 \\
\hline \multirow{2}{*}{3} & $\left\{\begin{array}{l}\text { Pectin } \\
\text { Pectic acid }\end{array}\right.$ & 31.3 & 11.15 \\
\hline
\end{tabular}

Titration sample $1.0 \mathrm{ml}$

Activities of the fractions 3 and 8 were estimated at $\mathrm{pH} 4.5$ and 5.5 , respectively.

tration of the preparation revealed the macerating activity on the disk of potato tuber. As demonstrated in the preceding section the enzyme preparation contained two kinds of liquefying pectolytic enzymes, which are known in other pathogens as tissue-macerating enzymes. Subsequent experiments were carried out, by the technique of zone electrophoresis, in order to elucidate the parallelism between the enzyme activities of $G$. kaki as measured by the reduction of viscosity of soluble pectic substances and the maceration of plant tissues.

The crude enzyme solution employed for the electrophoresis was prepared to give the concentration of 14,000 PMG-unit per ml. Enzyme elution from each segment was taken with 2 ml of water. Representative results are illustrated in Table 2. The macerating action on the potato disk was detected in the fractions 2 and 6 . Parallel determination of the pectin viscosity change showed that two maximum

Table 2. Zone electrophoresis of macerating activity and pectin depolymeric activity.

\begin{tabular}{|c|c|c|c|c|c|c|c|c|c|c|c|}
\hline & \multirow[b]{2}{*}{ Substrate } & \multicolumn{4}{|c|}{$\leftarrow$ Cathode } & \multicolumn{4}{|c|}{ Fractin No. } & \multirow[b]{2}{*}{2} & \multirow[b]{2}{*}{1} \\
\hline & & 10 & 9 & 8 & 7 & 6 & 5 & 4 & 3 & & \\
\hline Maceration of & $\int \mathrm{Kaki}$ & - & - & - & - & - & - & - & - & - & - \\
\hline the disk & Potato & - & - & - & - & H & - & - & - & + & - \\
\hline $\mathrm{A}_{1 \mathrm{hr}} \% \%^{a}$ & Pectin & 0 & 0 & 0 & 6.5 & 78.5 & 61.4 & 45.6 & 39.0 & 66.8 & 44.5 \\
\hline
\end{tabular}

$250 \mathrm{~V}, 4 \sim 5 \mathrm{~mA}, 15 \mathrm{hrs}$, $\mathrm{pH} 7.4$

${ }^{a}$ Eluate of each fraction was diluted by adding equal volume of water before estimation.

activities are found in the same fractions as the maceration was detected. In spite of the electrophoresis carried out by the same condition as that in Fig. 2, these enzyme fraction differed from those in the previous experiment. But it is feasible that the same enzymes, viz. endo-PG and endo-PMG, are found in the different segments, because the presence of other enzyme is hardly presumable. The 
disparities in the migration may be caused by the use of different concentrations of the enzyme preparation. The similarity in the electrophoretic migrations found in this section indicates that the maceration of potato tuber is caused by the actions of endo-PG and endo-PMG.

The endo-PMG fraction is mingled with cellulase $\mathrm{Cx}$, which is reported by Winstead ${ }^{15}$ ) as one of the macerating enzymes. But the similarity or possible identity of cellulase $\mathrm{Cx}$ and tissue-macerating enzyme has not been reported as in the case of tissue-macerating enzyme and pectolytic enzymes ${ }^{2,6,7,13,16)}$. Much more fundamental work may be necessary on this enzyme.
Table 3. Macerating activity of the crude enzyme preparation on the kaki and potato disks.

\begin{tabular}{ccc}
\hline PMG-unit $a$ & $\begin{array}{c}\text { Maceration of the disk } \\
\text { Kaki }\end{array}$ & $\begin{array}{c}\text { theto } \\
\text { Potato }\end{array}$ \\
\hline 4,000 & HWH & H \\
1,200 & - & H \\
300 & - & WH \\
150 & - & H \\
75 & - & H \\
37 & - & 土 \\
15 & - & - \\
\hline
\end{tabular}

a Indicated the activity in reaction mixture $(2.0 \mathrm{ml})$. In this paper, therefore, the problem concerning the cellulase $\mathrm{Cx}$ action in relation to the macerating activity will be reserved till further study is made.

A problem, however, still remains on the maceration of kaki fruit, because any fraction obtained in Table 2 did not act on the kaki disk. Comparison between the macerating activities on potato tuber and kaki fruit was taken to make this point clear. It was difficult to migrate the more concentrated preparation than 14,000 PMG-unit. Therefore, dilution test with the crude enzyme preparation was examined, and the obtained results are recorded in Table 3. The kaki disk was macerated only when the reaction mixture was prepared to be as active as 4,000 PMG-unit per $2 \mathrm{ml}$. This level of depolymeric activity is about 30 50 times as high as that required for the potato disk maceration. Thus, it is clear that the very active enzymes are required to macerate kaki fruit. No active fraction for the maceration of the potato and the kaki disks was obtained by the electrophoresis toward anode. The maceration of kaki fruit too would be mainly caused by endo-PG and endo-PMG.

\section{Discussion}

On a suitable medium G.kaki secretes considerable amounts of pectolytic enzymes, two of which are probably capable of macerating the tissues of kaki fruit and potato tuber. This evidence agrees with those of other soft rotting pathogens ${ }^{1,2,3,6 \sim 9,13,15,16)}$. As is proved in this paper, however, the preparation from the cultural filtrate of the causal fungus demands the potency of 2,000 PMG-unit per $\mathrm{ml}$ to macerate the kaki tissue, whereas the crude preparation from invaded kaki fruit is capable of macerating kaki fruit even when it is diluted to less than $1 \mathrm{PMG}$-unit per $\mathrm{ml}^{12)}$. Therefore, it is hardly presumable that in vivo these depolymeric enzymes cause the softening of kaki fruit. Moreover, at present, any macerating substance but endo-PG and endo-PMG has not been detected from the culture of the pathogen. These findings may support the presumption that softening of kaki fruit invaded by $G$. $k a k i$ would not be caused by the macerating enzymes from the pathogen but by those of the infected fruit itself.

\section{Summary}

When the fruit of kaki (Diospyros kaki Linn. f.) is invaded by Gloeosporium kaki Hori, the causal fungus of kaki anthracnose, softening occurs within the whole fruit. The experiments in this paper were chiefly performed to elucidate the connection between the macerating enzymes of the pathogen and the soft rotting of the host. The following results obtained indicate an impossibility of the fungal enzymes to cause the softening of kaki tissue in vivo. 
The crude preparation from soy liquid culture was found to contain considerable amounts of endo-PG, endo-PMG, exo-PG, and cellulase $\mathrm{Cx}$. Endo-PG and endo-PMG seemed to macerate the disks of potato tuber and kaki fruit, but no other macerating enzyme than these could be demonstrated. The experiment with the crude enzyme preparation from soy liquid culture showed that it required 2,000 PMG-unit per $\mathrm{ml}$ to macerate kaki fruit. The strength of this activity corresponds to about $30 \sim 50$ times of that required to macerate potato tuber. Such an active secretion has neither been detected on the kaki solid culture, nor on the soft rotted fruit invaded by the causal fungus.

(Received Apr. 26, 1962)

\section{Literature cited}

1. Ceponis, M. J. and Friedman, B. A. (1959). Phytopath. $49: 141-144$.

2. Echandi, E. and Walker, J. C. (1957). Ibid. $47: 303-306$.

3. Etchells, J. L., Bell, T. A., Monroe, R. L., Masley, P. M. and Demain, A. L. (1958). Appl. Microbiol. $6: 427-440$.

4. Hewitt, J. T. and Jones, W. J. (1919). Chem. Soc. Trans. $115: 193$.

5. Kaji, A. (1959). Mem. Fac. Agr. Kagawa Univ. (Japan) (4) : 27-28, 34, 45.

6. —_- Tachibana, S., Aihara, S. and Anabuki, Y. (1959). Tech. Bull. Fac. Agr. Kagawa Univ. (Japan) $11: 248-254$.

7. Singh, R. K. and Wood, R. K. S. (1956). Ann. Bot. N. S. $20: 89-103$.

8. Smith, W. K. (1958). J. Gen. Microbiol. $18: 33-41$.

9. Srivastava, D. N., Echandi, E. and Walker, J. C. (1959). Phytopath. 49: 145-148.

10. Tani, T. (1958). Tech. Bull. Fac. Agr. Kagawa Univ. (Japan) $9: 136-140$.

11. (1961). Ibid. $12: 235-241$.

12. Unpublished.

13. Tribe, H. T. (1955). Ann. Bot. N.S. $19: 351-368$.

14. Uritani, I. and Stahmann, M. A. (1961). Phytopath. $51: 277-285$.

15. Winstead, N. N. and McCombs, C. L. (1961). Ibid. $51: 270-273$.

16. Wood, R. K. S. (1955). Ann. Bot. N. S. $19: 1-27$.

\section{和交摘要}

カキ炭そ病菌の組織軟化酵素

谷利

カキ㟶そ病䍜病軟化果実には軟化起因物質が存在するにもかかわらず，病原菌 (Gloeosporium kaki Hori) はカキ果肉切片培地に液化型ペクチン質分解酵素をほとんど生産しない。しかし，その後の実験により，本 菌は希薄醬油液体培地に多量の液化型ペクチン質分解酵素を分泌することを知つたので, それらの酵素と果 実に検出される軟化起因物質との異同を明らかにする一助として本実験を括こなつた。

$25^{\circ} \mathrm{C}, 12$ 日間, 希薄滰油液体培地に培養した培養ろ液を硫安塩析, 透析してえた粗酵素液は, ペクチン, ペクチン酸, Na-CMC 溶液を液化するが, pectin-methylesterase の作用はしめさない。zone electrophoresis および作用型式から, 本粗酵素液中には endo-polygalacturonase, endo-polymethylgalacturonase, exo-polygalacturonase および cellulase Cx が存在することがわかつた。またジャがイモ切片の軟化は endo-PG および endo-PMG 作用が最高の区分にあらわれることから，本菌の組織軟化酵素として endo-PG 扣よび endo-PMG の 2 種を推定した。粗酵素のジャガイモ切片軟化作用は 75-PMG 単位/m1 であらわれるが，フ ユウガキ切片は 2,000 PMG-単位 $/ \mathrm{ml}$ でようやく軟化される。罹病軟化果実にはこのような高濃度のペクチ ン質液化力は検出されないので, 罹病果の軟化は菌の分泌する 2 種液化型ペクチン質分解酵素によるもので はないといえよう。

(香川大学農学部) 